\title{
Pengaruh struktur aktiva, likuiditas dan ukuran perusahaan terhadap struktur modal perusahaan farmasi yang listing di BEI periode 2015 sampai 2019
}

\author{
Ria Susanti Johan ${ }^{1} \&$ Desy Septariani² \\ 1,2 Universitas Indraprasta PGRI
}

\begin{tabular}{|c|c|}
\hline ARTICLE INFO & ABSTRAK \\
\hline $\begin{array}{l}\text { Article History: } \\
\text { Received Feb } 13^{\text {th }}, 2021 \\
\text { Revised April } 27^{\text {th }}, 2021 \\
\text { Accepted April } 29^{\text {th }}, 2021\end{array}$ & $\begin{array}{l}\text { Penelitian ini bertujuan untuk mengetahui pengaruh struktur aktiva, likuiditas dan } \\
\text { ukuran perusahaan, terhadap struktur modal. Jenis data yang digunakan adalah } \\
\text { data sekunder yang diperoleh dari BEI (Bursa Efek Indonesia) dan ICMD } \\
\text { (Indonesia Capital Market Direktori) } 2015 \text { sampai 2019. Populasi dalam penelitian } \\
\text { ini semua perusahaan farmasi yang terdaftar di BEl. Metode pengambilan }\end{array}$ \\
\hline $\begin{array}{l}\text { Keywords: } \\
\text { Struktur aktiva; } \\
\text { Likuiditas; } \\
\text { Ukuran perusahaan; } \\
\text { Struktur modal. }\end{array}$ & $\begin{array}{l}\text { sampelnya purposive sampling dengan } 8 \text { perusanaan tarmasl terpllin sebagal } \\
\text { sampel. Metode analisis yang digunakan adalah regresi linear berganda dengan } \\
\text { tingkat signifika } 0,05 \text {. Berdasarkan Hasil pengujian hipotesis ditemukan bahwa } \\
\text { struktur aktiva dan ukuran perusahaan berpengaruh positif dan signifikan pada } \\
\text { struktur modal perusahaan perusahaan farmasi yang terdaftar di Bursa Efek } \\
\text { Indonesia, sedangkan likuiditas tidak berpengaruh pada struktur modal } \\
\text { perusahaan farmasi pada Bursa Efek Indonesia tahun } 2015 \text { sampai } 2019 \text {. }\end{array}$ \\
\hline
\end{tabular}

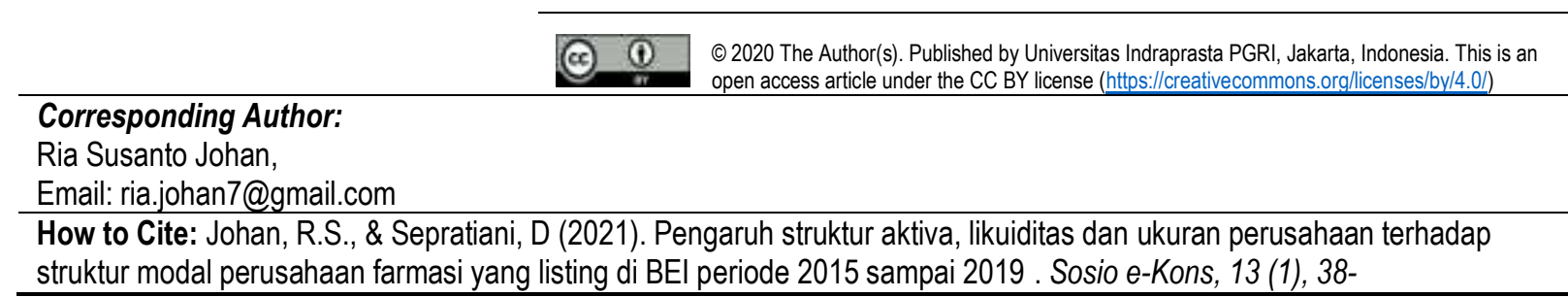

\section{PENDAHULUAN}

Perkembangan dunia bisnis terus mengalami kemajuan dan peningkatan, hal ini dapat dilihat dengan semakin banyaknya perusahaan yang tumbuh dan berkembang menjadi perusahaan besar denagn persaingan yang semakin ketat. Dalam menjalankan kegiatan perusahaan, pendanaan merupakan hal utama yang harus diperhatikan. Kelangsungan sebuah perusahaan salah satunya dipengaruhi oleh usaha manajer keuangan dalam meningkatkan keuangan perusahaan sehingga dapat memenuhi segala sesuatu yang dibutuhkan, dapat melakukan investasi melalui asset yang dimiliki sekaligus mengelola keuangan dengan sebaik mungkin. Pada saat ini perkembangan perekonomian terus mengalami peningkatan, yang ditandai dengan berdirinya perusahaan - perusahaan baru yang terus berkembang menjadi perusahaan besar. Untuk menghadapi persaingan ini diperlukan kecerdasan pelaku ekonomi melakukan strategi dalam persaingan, dan memiliki keunggulan dalam bersaing guna kemajuan perusahaan, baik itu para pesaing perusahaan yang berasal dari dalam negeri ataupun pesaing perusahaan yang berasal dari luar negeri atau yang memiliki modal lebih besar.Disamping itu perusahaan juga bisa melakukan pengembangan bisnisnya dalam menghadapi persaingan. Begitu pula dengan perusahaan farmasi juga akan menghadapi persaingan yang tinggi dari perusahaan lain dalam industri tersebut.

Perkembangan perekonomian yang mendukung lancarnya aktivitas ekonomi salah satunya sector farmasi yang memiliki peranan penting dalam bidang kesehatan baik di Indonesia maupun di luar Indonesia. Perusahaan farmasi merupakan salah satu sector yang diminati oleh calon investor, hal ini 
karena sector farmasi merupakan salah satu sector yang dibutuhkan ditengah kondisi perekonomian yang selalu menyediakan produk dan alat kesehatan sebagai prioritas utama setiap orang. Apalagi ditengah kondisi sekarang ini, permintaan terhadap obat dan alat kesehatan tergolong tinggi, karena pada saat ini kesehatan menjadi lebih utama bagi setiap orang.

Pada dasarnya perusahaan didirikan bertujuan untuk memaksimalkan laba dan meningkatkan kesejahteraan pemilik dengan cara meningkatkan nilai perusahaan. Kesejahteraan pemegang saham dapat dicerminkan melalui harga pasar perlembar saham perusahaan yang merupakan gambaran dari keputusan investasi, pendanaan dan manajemen aktiva. Jadi hal utama yang harus diperhatikan oleh perusahaan supaya tujuannya tercapai adalah dengan pendanaan atau modal yang berkaitan erat dengan kegiatan operasional perusahaan.

Modal atau dana adalah unsur terpenting untuk meningkatkan kegiatan perusahaan. Perusahaan yang mempunyai pendanaan besar, maka semakin besar kegiatan operasional yang dapat dijalankan. Pendanaan untuk meningkatkan produktivitas perusahaan ada yang berasal dari pihak luar yaitu dari pemegang saham dan hutang. Dilihat dari sifatnya tipe pendanaan ada dua. Pertama pendanaan yang berasal dari luar seperti pinjaman dan berasal dari penjualan surat berharga di pasar modal, dan yang ke dua pendanaan yang berasal dari dalam perusahan seperti dari laba ditahan. Struktur modal merupakan perbandingan dari long term debt dengan modal sendiri. Struktur modal yang baik dan tepat sangat dibutuhkan demi kelangsungan perusahaan, dikarenakan struktur modal berpengaruh langsung terhadap posisi keuangan perusahaan sekaligus berdampak terhadap nilai perusahaan. Dengan memiliki struktur modal yang optimal perusanaan akan jauh dari permasalahan pemborosan biaya modal. Ambarwati (2010:1) dalam (Saputri et al., 2020) mengatakan bahwa struktur modal adalah penggabungan antara kewajiban dan modal sendiri yang digunakan oleh perusahaan untuk merencanakan melalui hutang.

Brigham (2011:188-190) dalam (Harina, 2018) , Ada banyak faktor yang mempengaruhi struktur modal diantaranya stabilitas penjualan, struktur aktiva, leverage operasi, tingkat pertumbuhan, profitabilitas, pajak, pengendalian, sikap manajemen, sikap pemberi pinjaman dan lembaga pemeringkat, kondisi pasar, kondisi internal perusahaan dan fleksibilitas keuangan

Pengukuran struktur modal dapat dilakukan dengan rasio perbandingan antara total hutang terhadap modal sendiri melalui Debt to Equity Ratio(DER) (Husnan, 2011) dalam (Setiyanti et al., 2019). Perusahaan yang memiliki nilai DER tinggi, maka risiko yang akan dihadapi oleh perusahaan tersebut juga semakin tinggi, hal ini disebabkan oleh penggunaan hutang sebagai sumber pendanaan jauh lebih banyak dari pada modal sendiri. Perusahaan terbilang baik jika perusahaan tersebut bisa menentukan pendanaan yang rendah dengan bunga rendah dan dalam waktu fleksibel, sehingga utang menguntungkan untuk perusahaan. Dalam penelitian ini rasio yang digunakan dalam struktur modal yaitu Debt to Equity Ratio (DER). DER merupakan kemampuan perusahaan dalam membayar hutang dengan modal yang dimilikinya dan berkaitan erat dengan penciptaan struktur modal yang bisa berpengaruh pada kebijakan pendanaan perusahaan yang tepat guna memaksimalkan nilai perusahaan (Erdiana, 2011) dalam (Irza Nofriani, 2015). Nilai DER dihitung dengan Rumus Horne dan Wachowicz (2007 : 237) dalam (Hermawan, 2018).

$$
\text { DER }=\frac{\text { Total Debt }}{\text { Total Equity }} \times 100 \%
$$

Struktur aktiva menggambarkan sebagian jumlah aset yang dijadikan jaminan. Struktur aktiva menentukan besarnya alokasi pembagian untuk aktiva lancar dan aktiva tetap. Struktur aktiva merupakan perbandingan antara fixed assets dengan total assets. Struktur aktiva juga akan menentukan struktur long term liabilities (utang jangka panjang) dan Current Liabilities (utang jangka pendek) dalam perusahaan. Brigham (2011:118) dalam (Harina, 2018), menerangkan bahwa perusahaan yang memiliki asset yang layak digunakan sebagai jaminan pinjaman biasanya relatif banyak menggunakan utang. Hal ini menggambarkan bahwa perusahaan yang memiliki struktur aktiva 
yang tinggi maka akan semakin tinggi pula kemampuan perusahaan dalam menjamin long term liabilities yang dipinjamnya. Struktur aset adalah kekayaan yang dimiliki perusahaan dan bermanfaat pada masa yang akan datang dan dapat menghasilkan pendapatan untuk kegiatan operasional perusahaan (Viandy \& Dermawan, 2020). Proxy yang digunakan untuk mengukur struktur asset dalam penelitian ini adalah Tangibility (TANG) yang membandingkan total aset tetap dengan total keseluruhan asset. Nilai struktur aktiva menurut (Viandy \& Dermawan, 2020) dihitung dengan rumus:

$$
\text { Tangibility of Asset Ratio }(\mathrm{TANG})=\frac{\text { Total Fixed assets }}{\text { Total Assets }} \times 100
$$

Penelitian yang dilakukan oleh Joni dan Lina (2010), Baharuddin (2011) dan Indrajaya (2011) dalam (Suweta \& Dewi, 2016) menemukan bahwa struktur aktiva berpengaruh positif dan signifikan dengan struktur modal. Hasil penelitian (Novyarni \& Wati, 2018) menemukan bahwa struktur aset berpengaruh terhadap struktur modal pada perusahaan manufaktur di BEI tahun 2012-2015. Lain halnya dengan penelitian yang dilakukan oleh (Viandy \& Dermawan, 2020) yang menemukan bahwa Struktur aset berpengaruh negatif dan tidak signifikan terhadap struktur modal. Begitu juga dengan penelitian yang dilakukan oleh (Suweta \& Dewi, 2016) struktur aktiva berpengaruh positif dan signifikan terhadap struktur modal pada Restaurant Pawitra Sari di Ubud tahun 2011-2014. Berbeda dengan penelitian Penelitian Sheikh (2011) dalam (Suweta \& Dewi, 2016) menyatakan bahwa struktur aktiva berpengaruh negatif dan tidak signifikan terhadap struktur modal.

Ukuran perusahaan atau Firm size merupakan salah satu dari variabel yang berpengaruh dengan struktur modal. Ukuran perusahaan menurut (Riyanto, 2011:59) dalam (Munafi'ah et al., 2017) adalah besar kecilnya perusahaan yang dilihat dari nilai ekuitas, nilai perusahaan, serta hasil nilai total aktiva dari suatu perusahaan. Semakin besar sebuah perusahaan, maka keinginan untuk menggunakan modal asing dalam kegiatan perusahaan juga semakin besar. Hal ini disebabkan perusahaan yang besar akan membutuhkan dana yang besar juga untuk kegiatan operasionalnya, dan jalan yang ditempuh salah satunya adalah melalui modal asing karena modal sendiri tidak mencukupi (Halim, 2007:89) dalam (Munafi'ah et al., 2017). Ukuran perusahaan merupakan gambaran kemampuan finansial perusahaan dalam suatu periode tertentu berdasarkan aset yang dimiliki. Nadeem dan Wang (2011:124) dalam (Arini, 2019) firm size yang merupakan indikator besar kecilnya perusahaan diukur dengan menggunakan natural logaritma total aset perusahaan atau Size $=\operatorname{Ln}$ (total aset).

Calon Investor untuk memutuskan melakukan investasi akan melihat seberapa besar perusahaan tersebut, investor berpendapat bahwa perusahaan dengan skala besar lebih stabil dan lebih sanggup menghasilkan profit tinggi dibandingkan perusahaan dengan skala yang masih kecil. Semakin besar ukuran perusahaan, maka akan semakin banyak investor yang tertarik dengan perusahaan tersebut. Hal ini berarti besar atau kecilnya ukuran sebuah perusahaan akan berdampak terhadap strategi struktur modal perusahaan. Ukuran perusahaan mencerminkan besar atau kecilnya sebuah perusahaan yang dapat dilihat dari jumlah assetnya, jumlah penjualan, rata-rata tingkat penjualan dan rata- rata total asset, akibatnya perusahaan yang kecil akan mengalami kesulitan dalam mendapatkan pinjaman dibandingkan dengan perusahaan besar, jadi besar kecilnya ukuran perusahaan sangat berpengaruh terhadap struktur modal.

Penelitian tentang size perusahaan terhadap struktur modal perusahaan sebelumnya telah dilakukan oleh peneliti terdahulu. Penelitian (Krisnanda \& Wiksuana, 2015) yang menghasilkan bahwa bahwa ukuran perusahaan mempunyai pengaruh yang negatif dan tidak signifikan dengan struktur modal perusahaan telekomunikasi di BEI tahun 2010-2013. Lain halnya dengan penelitian (Harina, 2018) yang menemukan bahwa ukuran perusahaan mempunyai pengaruh yang positif dan signifikan terhadap struktur modal perusahaan property \& real estate di BEI periode 2011-2016. Berbeda dengan hasil penelitian yang dilakukan oleh (Irza Nofriani, 2015) yang menemukan bahwa ukuran perusahaan tidak berpengaruh terhadap struktur modal perusahaan manufaktur yang terdaftar di BEI tahun 20102013. Lain halnya dengan hasil penelitian (Novyarni \& Wati, 2018) yang menemukan bahwa ukuran 
perusahaan berpengaruh terhadap struktur modal pada perusahaan manufatur di BEI tahun 2012 sampai 2015. Begitu juga dengan penelitian yang dilakukan oleh (Ayu et al., 2016) yang membuktikan bahwa adanya pengaruh yang positif dan signifikan firm size secara parsial terhadap struktur modal.

Faktor lain yang juga mempengaruhi struktur modal perusahaan adalah likuiditas. Likuiditas merupakan kemampuan perusahaan dalam memenuhi kewajiban jangka pendeknya. Rasio likuiditas merupakan salah satu indikator tentang kemampuan perusahaan membayar semua kewajiban finansial jangka pendek saat jatuh tempo dengan menggunakan aktiva lancarnya. Semakin tinggi nilai rasio likuiditas suatu perusahaan artinya kemampuan perusahaan dalam memenuhi kewajiban jangka pendeknya juga semakin baik (Seftianne, 2011) dalam (Ningsih, 2015). Aspek likuiditas tergolong bagian yang penting untuk dilakukan penilaian yang ada hubungannya dengan struktur modal. Likuiditas sebuah perusahaan tercermin dari kemampuan aset yang dimiliki perusahaan dalam memenuhi kewajiban jangka pendek yang berkaitan dengan modal perusahaan. Perusahaan yang bisa dengan cepat melunasi hutangnya akan mendapat kepercayaan dari kreditur yang akan memberikan hutang dalam jumlah yang cukup besar. Selain itu kemungkinan perusahaan akan menghadapi risiko keuangan yang mengakibatkan kewajiban tidak dapat dibayarkan. Perusahaan dengan likuiditas yang tinggi lebih memilih tidak menggunakan pembiayaan melalui hutang. Ini dikarenakan perusahaan dengan likuiditas yang tinggi memiliki dana internal yang lebih besar, sehingga perusahaan lebih memilih untuk menggunakan dana internalnya yang dimiliki terlebih dahulu untuk pembiayaan investasi sebelum menggunakan pembiayaan eksternal dengan hutang. Proxy likuiditas dalam penelitian ini diwakilkan dengan adalah Current Ratio (CR) yang membandingkan aset lancar (current assets) dengan hutang lancar (current liabilities). Current ratio yang tinggi menunjukkan perusahaan dapat menutupi kewajiban jangka pendek secara tepat waktu. Current Ratio dihitung dengan menggunakan rumus berikut ini.

Current Ratio $=\frac{\text { Current Assets }}{\text { Current Liabilities }} \times 100 \%$

Penelitian yang dilakukan oleh (Viandy \& Dermawan, 2020) membuktikan bahwa Likuiditas berpengaruh negatif dan signifikan terhadap struktur modal perusahaan manufaktur yang terdaftar di BEI periode 2015-2017. Hasil yang sama ditemukan oleh (Hamidah et al., 2016) dimana variabel Likuiditas berpengaruh negatif terhadap Struktur Modal pada perusahaan di BEI tahun 2011-2014. Hasil penelitian yang sama juga ditemukan oleh (Saputri et al., 2020) dimana variabel likuiditas berpengaruh terhadap struktur modal. Berbeda dengan hasil penelitian yang dilakukan oleh (Ramadhanti, 2018) yang menemukan bahwa Likuditas tidak berpengaruh terhadap struktur modal sektor property dan real estate yang terdapat di BEl periode 2014-2018.

Pada table di bawah ini dapat dilihat struktur modal perusahaan farmasi dari tahun 2015 sampai tahun 2019.

Tabel 1 Nilai Struktur Modal perusahan farmasi tahun 2015 sampai 2019.

\begin{tabular}{cccccc}
\hline Perusahaan & 2015 & 2016 & 2017 & 2018 & 2019 \\
\hline DVLA & $41 \%$ & $42 \%$ & $47 \%$ & $40 \%$ & $40 \%$ \\
SIDO & $8 \%$ & $8 \%$ & $9 \%$ & $15 \%$ & $15 \%$ \\
KLBF & $2,24 \%$ & $2,27 \%$ & $2,27 \%$ & $2,33 \%$ & $2,24 \%$ \\
KAEF & $74 \%$ & $103,07 \%$ & $122,12 \%$ & $173,4 \%$ & $147,58 \%$ \\
SCPI & $1.398 \%$ & $495 \%$ & $279 \%$ & $241 \%$ & $254 \%$ \\
MERK & $35 \%$ & $28 \%$ & $38 \%$ & $144 \%$ & $52 \%$ \\
PYFA & $58 \%$ & $58 \%$ & $46,58 \%$ & $57,29 \%$ & $52,96 \%$ \\
TSPC & $44,90 \%$ & $42,08 \%$ & $46,30 \%$ & $44,86 \%$ & $44,58 \%$ \\
\hline
\end{tabular}

Pada table 1 di atas dapat dilihat bahwa struktur modal perusahaan mengalami kenaikan dan penurunan yang berfluktuatif. Hal ini bisa disebabkan oleh kenaikan atau peningkatan ukuran perusahaan, likuiditas bahkan struktur aktiva perusahaan. Berdasarkan uraian dan perbedaan hasil 
penelitian di atas, untuk itu penulis ingin melakukan penelitian kembali tentang variabel yang mempengaruhi Struktur modal perusahaan tahun 2015 sampai 2019 pada perusahaan Farmasi yang listing di BEI.

\section{METODE}

Jenis data yang digunakan adalah data kuantitatif, yaitu data yang diukur melalui angka-angka yang dapat dihitung (Sugiyono,2009) dalam (Hermawan, 2018). Data pada penelitian ini adalah data sekunder yang berupa laporan keuangan perusahaan yang telah dipublikasikan. Tempat penelitian ini berada di Bursa Efek Indonesia (BEI) dengan mengakses website www.idx.co.id dan Indonesia Capital Market Directory (ICMD). Teknik analisis data menggunakan regresi linear berganda. Populasi dalam penelitian ini adalah semua perusahaan Farmasi yang terdaftar di Bursa Efek Indonesia (BEI) periode 2015 sampai 2019, dengan jumlah sampel sebanyak 8 perusahaan farmasi. Pengambilan sample dengan metode Non probability Sampling dengan tekniknya purposive sampling yaitu pengambilan sampel berdasarkan dengan kriteria tertentu (Fernandes Moniaga, 2013). Adapun kriteria yang digunakan sebagai berikut:

1. Perusahaan farmasi yang masih terdaftar di bursa efek indonesia selama tahun 2015 sampai 2019.

2. Perusahaan farmasi yang memiliki laporan keuangan yang lengkap dari tahun 2015 sampai 2019.

3. Perusahaan pada tahun tertentu yang tidak memenuhi salah satu kriteria yang telah ditetapkan, maka perusahaan tersebut tidak dimasukkan ke dalam sampel penelitian.

\section{HASIL DAN PEMBAHASAN}

\section{Uji Asumsi Klasik}

Normalitas

Uji normalitas dilakukan untuk mengetahui model regresi yang digunakan normal dengan melihat histogram atau probabilitas plot. Dari hasil pengujian diperoleh data yang digunakan normal, karena poligon tidak menceng ke kiri atau ke kanan dan titik-titik probability plot menyebar digaris diagonal.

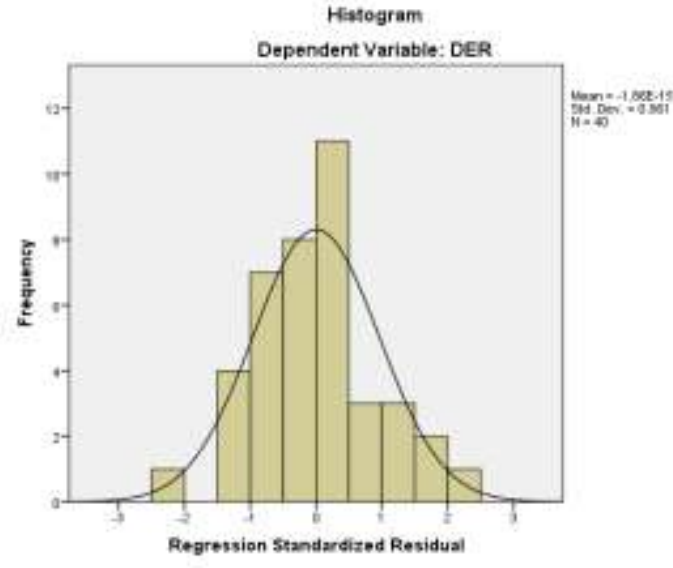

Gambar 1 Histogram

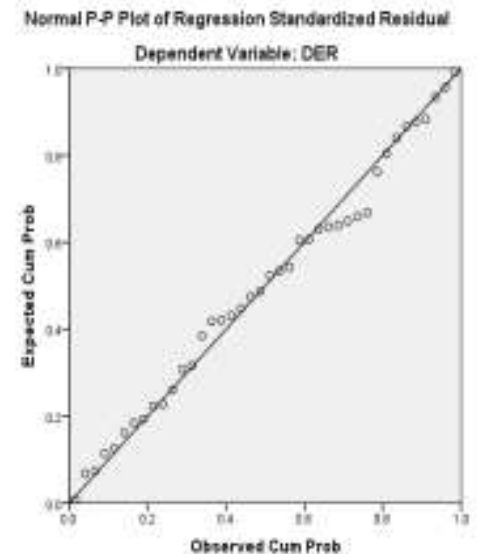

Gambar 2 P-P Plot

\section{Multikolinearitas}

Hasil pengujian yang telah dilakukan membuktikan bahwa model regresi yang digunakan tidak terdapat masalah multikolinearitas dengan nilai tolerance di atas 0,1 dan VIP dibawah 10. 
Tabel 2. Uji Multikolineartitas

\begin{tabular}{|c|c|c|c|c|c|c|c|c|c|c|c|}
\hline \multicolumn{12}{|c|}{ Coefficients $^{\mathrm{a}}$} \\
\hline \multirow[b]{2}{*}{ Model } & & \multicolumn{2}{|c|}{$\begin{array}{l}\text { Unstandardized } \\
\text { Coefficients }\end{array}$} & \multirow{2}{*}{$\begin{array}{c}\text { Standardized } \\
\text { Coefficients } \\
\text { Beta }\end{array}$} & \multirow[t]{2}{*}{$\mathrm{t}$} & \multirow[t]{2}{*}{ Sig. } & \multicolumn{3}{|c|}{ Correlations } & \multicolumn{2}{|c|}{ Collinearity Statistics } \\
\hline & & B & Std. Error & & & & $\begin{array}{l}\text { Zero- } \\
\text { order }\end{array}$ & Partial & Part & Tolerance & VIF \\
\hline 1 & (Constant) & 16.042 & 3.610 & & 4.444 & .000 & & & & & \\
\hline & TANG & .777 & .245 & -.440 & 3.169 & .003 & -.432 & -.467 & -.440 & .999 & 1.001 \\
\hline & CR & -.231 & .189 & -.205 & -1.223 & .229 & .015 & -200 & -.170 & .688 & 1.453 \\
\hline & Ln_size & .262 & .105 & -.417 & 2.496 & .017 & -.288 & -.384 & -.346 & .688 & 1.453 \\
\hline
\end{tabular}

a. Dependent Variable: DER

\section{Autokorelasi}

Untuk mengetahui tidak adanya autokorelasi dalam regresi dilihat dengan metode Durbin Watson dengan syarat $-2<d w<2$, angka dw terletak antara -2 dan +2 Singgih Santoso (2008:219) dalam (Septariani \& Johan, 2018). Hasil penelitian diperoleh nilai Durbin Watson 0,748 yang berada diantara 2 dan +2 , dengan kesimpulan penelitian ini bebas dari autokorelasi.

Tabel 3. Uji Autokorelasi

Model Summaryb

\begin{tabular}{|c|c|c|c|c|c|c|c|c|c|c|}
\hline \multirow[b]{2}{*}{ Mode } & \multirow[b]{3}{*}{$R$} & \multirow[b]{3}{*}{ R Square } & \multirow[b]{2}{*}{ Adjusted R } & \multicolumn{6}{|c|}{ Change Statistics } & \multirow[b]{3}{*}{ Durbin-Watson } \\
\hline & & & & Std. Error of & R Square & $\mathrm{F}$ & & & Sig. F & \\
\hline I & & & Square & the Estimate & Change & Change & df1 & df2 & Change & \\
\hline 1 & $.554^{\mathrm{a}}$ & .307 & .250 & 1.18330 & .307 & 5.323 & 3 & 36 & .004 & .748 \\
\hline
\end{tabular}

a. Predictors: (Constant), Ln_size, TANG, CR

b. Dependent Variable: DER

\section{Heteroskedastisitas}

Penelitian mengalami Heteroskedastisitas jika grafik scatterplott membentuk pola tertentu atau teratur (bergelombang, menyebar, menyempit). Hasil pengujian membuktikan tidak terjadi heteroskedastisitas dalam model yang digunakan dikarenakan titik-titik menyebar secara acak dan di atas atau dibawah angka nol sumbu $Y$.

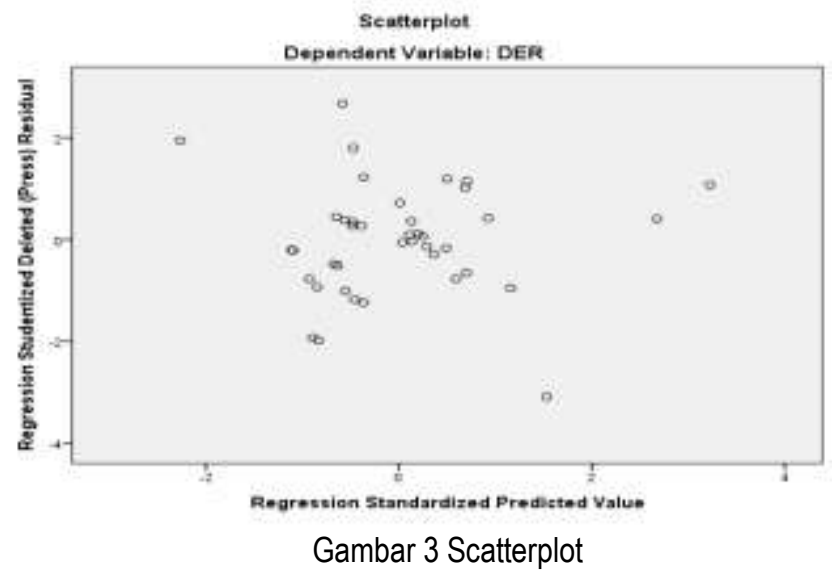

Berdasarkan pengujian dengan SPSS maka persamaan regresi dalam penelitian ini adalah $Y=16,042+0,777$ Tang $-0,231 \mathrm{CR}+0,262$ Size 
Tabel 4. Hasil regresi linear berganda

Coefficients $^{a}$

\begin{tabular}{|c|c|c|c|c|c|c|c|c|c|c|c|}
\hline \multirow[b]{2}{*}{ Model } & & \multicolumn{2}{|c|}{$\begin{array}{l}\text { Unstandardized } \\
\text { Coefficients }\end{array}$} & \multicolumn{3}{|c|}{$\begin{array}{c}\text { Standardized } \\
\text { Coefficients }\end{array}$} & \multicolumn{3}{|c|}{ Correlations } & \multicolumn{2}{|c|}{ Collinearity Statistics } \\
\hline & & B & Std. Error & Beta & $t$ & Sig. & $\begin{array}{l}\text { Zero- } \\
\text { order }\end{array}$ & Partial & Part & Tolerance & VIF \\
\hline 1 & (Constant) & 16.042 & 3.610 & & 4.444 & .000 & & & & & \\
\hline & TANG & .777 & .245 & -.440 & 3.169 & .003 & -.432 & -.467 & -.440 & .999 & 1.001 \\
\hline & $\mathrm{CR}$ & -.231 & .189 & -.205 & -1.223 & .229 & .015 & -.200 & -.170 & .688 & 1.453 \\
\hline & Ln_size & .262 & .105 & -.417 & 2.496 & .017 & -.288 & -.384 & -.346 & .688 & 1.453 \\
\hline
\end{tabular}

a. Dependent Variable: DER

\section{Uji Goodness Of Fit}

Berdasarkan hasil pengujian yang dilakukan diperoleh nilai $R$ Square nya sebesar 0,307 atau $30,7 \%$, yang menunjukkan bahwa struktur modal perusahaan yang diwakilkan dengan DER dapat dijelaskan oleh variabel struktur aktiva, ukuran perusahaan dan CR sebesar 30,7\%, sisanya 69,3\% dipengaruhi faktor-faktor lain yang tidak dijelaskan pada penelitian ini.

Tabel 5. Uji Goodness of fit Model Summary ${ }^{b}$

\begin{tabular}{|c|c|c|c|c|c|c|c|c|c|c|}
\hline \multirow[b]{3}{*}{ Model } & \multirow[b]{3}{*}{$R$} & \multirow{3}{*}{$\begin{array}{c}\mathrm{R} \\
\text { Square }\end{array}$} & \multirow{3}{*}{$\begin{array}{c}\text { Adjusted R } \\
\text { Square }\end{array}$} & \multirow{3}{*}{$\begin{array}{l}\text { Std. Error of } \\
\text { the Estimate }\end{array}$} & \multicolumn{4}{|c|}{ Change Statistics } & \multirow[b]{3}{*}{ Sia F Change } & \multirow[b]{3}{*}{ Durbin-Watson } \\
\hline & & & & & R Square & $\mathrm{F}$ & & & & \\
\hline & & & & & Change & Change & df1 & df2 & & \\
\hline 1 & $.554^{a}$ & .307 & .250 & 1.18330 & .307 & 5.323 & 3 & 36 & .004 & .748 \\
\hline
\end{tabular}

a. Predictors: (Constant), Ln_size, Tang, CR

b. Dependent Variable: DER

\section{Uji F}

Uji $\mathrm{F}$ untuk mengetahui apakah semua variabel independen berpengaruh secara bersamasama terhadap variabel dependennya. Apabila nilai $\mathrm{F}$ hitung $>\mathrm{F}$ tabel , maka $\mathrm{HO}$ ditolak, dan jika $\mathrm{F}$ hitung < F tabel, maka Ho diterima. Ha diterima: $\rho<0,05$ Ho ditolak Ha ditolak: $\rho>0,05$ Ho diterima. Hasil regresi linear berganda menyatakan variabel independen secara bersama- sama berpengaruh signifikan terhadap variabel dependen, dengan nilai $F$ hitung 5,323 lebih besar dari $F$ tabel 2,87 (5,323 $>2,87$ ) dengan ( $\mathrm{df}=3$ dan 36 ) dengan nilai signifikannya 0,04 . Karena probabilitas lebih kecil dari 0,05 , maka model bisa digunakan memprediksi struktur modal atau DER. Jadi secara simultan struktur aktiva, ukuran perusahaan dan current ratio berpengaruh signifikan terhadap DER.

Tabel 5 Uji F

ANOVA $^{\mathrm{a}}$

\begin{tabular}{ccccccc}
\hline & Model & Sum of Squares & Df & Mean Square & $F$ & Sig. \\
\hline 1 & Regression & 22.361 & 3 & 7.454 & 5.323 & $.004^{\mathrm{b}}$ \\
& Residual & 50.407 & 36 & 1.400 & & \\
Total & 72.768 & 39 & & & \\
\hline
\end{tabular}

a. Dependent Variable: DER

Uji t

b. Predictors: (Constant), Ln_size, TANG, CR

Uji t dilakukan untuk membuktikan seberapa besar pengaruh variabel independen secara individual terhadap variabel dependen, Dengan syarat Ha diterima: $\rho<0,05$ Ho ditolak. Ha ditolak: $\rho\rangle$ 0,05 Ho diterima. Jika nilai $t$ hitung $>t$ tabel, Ho ditolak, dan Jika $t$ hitung $<t$ tabel, Ho diterima. Dari hasil analisis regresi variabel independen struktur aktiva (TANG atau X1) berpengaruh terhadap variabel Struktur modal dengan proxy debt to equity ratio (DER) dengan nilai signifikannya 0,03 lebih kecil dari $0,05(0,03<0,05)$. Variabel likuiditas dengan proxy current ratio (CR atau X2) tidak berpengaruh terhadap struktur modal dalam hal ini debt to equity ratio (DER), karena memiliki nilai signifikannya 0,229 lebih besar dari tingkat signifikan $0,05(0,229>0,05)$. Selanjutnya variabel firm size 
atau X3 berpengaruh signifikan terhadap debt to equity ratio (DER) dengan nilai signifikannya 0,017 lebih kecil dari $0,05(0,017<0,05)$.

\section{Pengujian Hipotesis}

Hipotesis Pertama Struktur aktiva atau TANG (X1) berpengaruh positif dan signifikan terhadap struktur modal yang diwakilkan oleh debt to equity ratio (DER). Hasil pengujian diperoleh nilai koefisien regresi TANG 0,777 , dengan t hitungnya bertanda positif sebesar 3,169 dengan nilai signifikannya 0.003 lebih kecil dari $0,05(0,003<0,05)$, artinya hipotesis Pertama diterima dimana struktur aktiva berpengaruh positif dan signifikan terhadap struktur modal yang diwakilkan dengan debt to equity ratio (DER). Hasil penelitian ini sejalan dengan penelitian (Suweta \& Dewi, 2016) yang menemukan bahwa struktur aktiva memiliki pengaruh yang positif dan signifikan terhadap struktur modal pada restoran Pawitra sari di Ubud tahun 2011 sampai tahun 2014. Ini menjelaskan bahwa semakin tinggi struktur aktiva sebuah perusahaan, maka semakin tinggi juga struktur modal perusahaan tersebut, akibatnya perusahaan akan lebih mudah memperoleh dana dana atau pinjaman hutang dari pihak luar atau eksternal dengan menjaminkan aktiva tetap yang dimiliki oleh perusahaan tersebut dalam pembayaran hutangnya bahkan akan memperoleh pinjaman dalam mengatasi kesulitan keuangan perusahaan. Ini juga mencerminkan bahwa dalam memperoleh hutang perusahaan menggunakan aktiva tetap untuk jaminannya. Hal ini berarti perusahaan yang memiliki aktiva tetap yang tinggi, akan mendapatkan peluang yang lebih besar dalam memperoleh hutang jangka panjang.

Hipotesis kedua likuiditas dengan proxy Current ratio atau CR (X2) berpengaruh positif dan signifikan terhadap struktur modal yang diwakilkan dengan debt to equity ratio (DER). Hasil pengujian yang sudah dilakukan diperoleh koefisien regresi CR sebesar $-0,231$, nilai $t$ hitung bertanda negatif sebesar $-1,223$, dengan signifikannya 0,229 lebih besar dari 0,05 $(0,229>0,05)$, yang artinya hipotesis kedua $(\mathrm{H} 2)$ ditolak, sehingga current ratio $(\mathrm{X} 2)$ tidak berpengaruh terhadap struktur modal yang diwakilkan dengan debt to equity ratio (DER). Hal ini dikarenakan oleh semakin rendah kemampuan perusahaan dalam melunasi kewajiban jangka pendeknya maka mengindikasikan perusahaan berada dalam keadaan yang tidak sehat. Hasil penelitian ini sejalan dengan penelitian yang dilakukan oleh (Yoshendy et al., 2015) . Penelitian ini juga sama dengan penelitian yang dilakukan oleh (Ramadhanti, 2018) yang menemukan bahwa likuiditas tidak berpengaruh terhadap struktur modal perusahaan property dan real estate tahun 2014 sampai 2018. Hasil penelitian ini juga didukung oleh penelitian (Zulkarnain, 2020) yang membuktikan bahwa likuiditas tidak signifikan terhadap struktur modal perusahaan perusahaan food and beverages di BEI pada tahun 2013 sampai 2018. Hal ini dikarenakan umunya nilai likuiditas pada perusahaan ini lebih tinggi daripada nilai struktur modal (DER) yang dimiliki. Hal ini mencerminkan bahwa semakin rendah kemampuan perusahaan dalam melunasi kewajibankewajiban jangka pendeknya maka hal dapat mengindikasikan perusahaan berada dalam keadaan yang tidak sehat sehat.

Hipotesis ketiga ukuran perusahaan atau firm size (X3) berpengaruh positif dan signifikan terhadap struktur modal yang diwakilkan dengan debt to equity ratio. Hasil pengujian diperoleh nilai koefisien regresi size sebesar 0,262 , nilai t hitung bertanda positif sebesar 2,496 dengan signifikannya 0,017 lebih kecil dari $0,05(0,017<0,05)$, yang artinya firm size berpengaruh positif dan signifikan terhadap struktur modal yang diwakilkan dengan debt to equity ratio. Hasil penelitian ini sejalan dengan penelitian yang dilakukan oleh (Siti Nurlaela, 2017) yang menemukan bahwa adanya pengaruh yang signifikan ukuran perusahaan terhadap struktur modal perusahaan kosmetik dan household di BEI tahun 2010 sampai 2015. Penelitian ini juga didukung oleh hasil penelitian (Harina, 2018) yang membuktikan bahwa ukuran perusahaan memiliki pengaruh yang positif dan signifikan terhadap struktur modal perusahaan property dan real estate yang terdaftar di BEI pada periode 2011 sampai 2016. Hasil ini mendukung pernyataan Hanafi (2004:321) dalam (Siti Nurlaela, 2017) bahwa perusahaan yang besar cenderung terdiversivikasi sehingga menurunkan resiko kebangkrutan. Hasil penelitian ini membuktikan bahwa semakin besar nilai firm size maka struktur modal perusahaan akan semakin besar juga. Perusahaan yang ukuran lebih besar dianggap lebih bisa mengahadapi krisis atau masalah 
dalam kegiatan perusahaan. Perusahaan yang ukuran besar lebih mudah mendapatkan pinjaman kreditur. Sehingga dapat disimpulkan semakin besar ukuran perusahaan maka akan semakin besar dana yang dibutuhkan dan semakin besar ukuran perusahaan maka struktur modal perusahaan akan semakin besar juga.

\section{SIMPULAN DAN SARAN}

Berdasarkan pada pembahasan hasil pengujian hipotesis yang sudah dilakukan maka dapat diajukan beberapa kesimpulan yaitu: (1) Secara simultan struktur aktiva, likuiditas dan ukuran perusahaan berpengaruh terhadap struktur modal pada perusahaan farmasi yang listing di BEI tahun 2015 sampai 2019. (2) Secara parsial struktur aktiva dan ukuran perusahaan berpengaruh terhadap struktur modal perusahaan farmasi yang terdaftar di BEI. Ini menjelaskan bahwa semakin tinggi struktur aktiva sebuah perusahaan, maka semakin tinggi juga struktur modal perusahaan tersebut, akibatnya perusahaan akan lebih mudah memperoleh dana dana atau pinjaman hutang dari pihak luar atau eksternal dengan menjaminkan aktiva tetap yang dimiliki oleh perusahaan tersebut. ini membuktikan bahwa semakin besar nilai firm size maka struktur modal perusahaan akan semakin besar juga. Perusahaan yang ukuran lebih besar dianggap lebih bisa mengahadapi krisis atau masalah dalam kegiatan perusahaan. Perusahaan yang ukuran besar lebih mudah mendapatkan pinjaman kreditur. Sedangkan secara parsial variabel likuiditas tidak memiliki pengaruh terhadap struktur modal perusahaan farmasi yang terdaftar di BEI tahun 2015 sampai 2019. Hal ini dikarenakan oleh semakin rendah kemampuan perusahaan dalam melunasi kewajiban jangka pendeknya maka mengindikasikan perusahaan berada dalam keadaan yang tidak sehat.

Untuk peneliti selanjutnya yang tertarik melakukan penelitian tentang yang mempengaruhi struktur modal perusahaan, diharapkan dapat menambah jumlah variabel independan dalam penelitian seperti risiko bisnis, growth opportunity, kebijakan dividen, operating leverage, pajak serta mengubah objek penelitian yang digunakan seperti perusahaan non manufaktur agar hasil penelitian yang ditemukan lebih baik lagi.

\section{REFERENCES/DAFTAR PUSTAKA}

Arini, F. (2019). Pengaruh Likuiditas, Ukuran Perusahaan, Struktur Aktiva, Profitabilitas, dan Pertumbuhan Penjualan Terhadap Struktur Modal. Fakultas Ekonomi Dan Bisnis Universitas Brawijaya Malang, 53(9), 1689-1699.

Ayu, I., Kusuma, D., Cipta, W., \& Suwendra, I. W. (2016). Pengaruh Ukuran Perusahaan, Pertumbuhan Penjualan, dan Profitabilitas Terhadap Struktur Modal Pada Perusahaan Manufaktur. E-Journal Bisma Universitas Pendidikan Ganesha, 4.

Fernandes Moniaga. (2013). Struktur Modal, Profitabilitas Dan Struktur Biaya Terhadap Nilai Perusahaan Industri Keramik, Porcelen Dan Kaca Periode 2007 - 2011. Jurnal EMBA, Vol.1 No 4(4), Hal. 433-442.

Hamidah, H., Iswara, D., \& Mardiyati, U. (2016). The Effect Of Profitability, Liquidity, Growth Sales Operating Leverage And Tangibility On Capital Structure(evidence from manufacture firm listed on Indonesia stock exchange in 2011- 2014). JRMSI - Jurnal Riset Manajemen Sains Indonesia, 7(1), 96.

Harina, E. T. (2018). Pengaruh Profitabilitas, Pertumbuhan Penjualan, Struktur Aktiva Dan Ukuran Perusahaan Terhadap Struktur Modal Pada Perusahaan Property Dan Real Estate Yang Terdaftar Di Bursa Efek Indonesia. Jurnal Ecogen, 1(1), 87.

Hermawan, A. D. (2018). Pengaruh Kebijakan Deviden, Growth Opportunity dan Struktur Modal terhadap Nilai Perusahaan dengan Kepemilikan Manajerial sebagai Variabel Intervening. Sosio 
E-Kons, 10(2), 131.

Irza Nofriani. (2015). Pengaruh Profitabilitas, Ukuran Perusahaan, Pertumbuhan Penjualan, Pertumbuhan Aset, dan Likuiditas Terhadap Struktur Modal Pada Perusahaan Manufaktur yang terdaftar di Bursa Efek Indonesia periode 2010-2013. Universitas Maritim Raja Ali Haji, Tanjungpinang.

Krisnanda, P. H., \& Wiksuana, I. G. B. (2015). Pengaruh Ukuran Perusahaan, Pertumbuhan Penjualan, dan Non-Debt Tax Shield Terhadap Struktur Modal Pada Perusahaan Telekomunikasi di BEl. $4(5), 1434-1451$.

Munafi'ah, I., Suprijanto, A., \& Hartono. (2017). Pengaruh Profitabilitas, Likuiditas, Ukuran Perusahaan, Pertumbuhan Penjualan, Struktur Aktiva dan Risiko Bisnis terhadap Struktur Modal. EkonomiAkuntansi, 1-20.

Ningsih, D. W. (2015). Pengaruh Profitabilitas, Likuiditas, Pertumbuhan Penjualan dan Ukuran Perusahaan terhadap Struktur Modal. Universitas Muhammdiyah Yogyakarta, 1-22.

Novyarni, N., \& Wati, L. (2018). Pengaruh Pertumbuhan Penjualan, Ukuran Perusahaan, Struktur Aset dan Profitabilitas Terhadap Struktur Modal Pada Perusahaan Manufaktur Yang terdaftar di BEI Tahun 2012-2015. 27(02), 253-285.

Ramadhanti, S. H. (2018). Pengaruh Likuiditas, Ukuran Perusahaan, Pertumbuhan Penjualan, Profitabilitas, dan Struktur Aset terhadap Struktur Modal. Fakultas Ekonomi \& Bisnis Universitas Ahmad Dahlan, 1-23.

Saputri, intan P., Nurlaela, S., \& Titisari, K. H. (2020). Profitabilitas, Likuiditas, Struktur Aktiva, Ukuran Perusahaan, Pertumbuhan Penjualan dan Struktur Modal Perusahaan Restoran, Hotel \& Pariwisata. Jurnal Penelitian Ekonomi Dan Akuntansi (JPENSI), 5(1), 91-107.

Septariani, D., \& Johan, R. S. (2018). Analisis Pengaruh Struktur Modal terhadap Profitabilitas pada Perusahaan LQ45 di BEI Periode 2012-2016. Sosio E-Kons, 10(3), 261.

Setiyanti, S. W., SR, D. P., \& Pari, R. K. U. (2019). Pengaruh Profitabilitas, Ukuran Perusahaan, Struktur Aktiva dan pertumbuhan Penjualan Terhadap Struktur Modal Pada Perusahaan Manufaktur Yang Terdaftar Di BEI Periode 2012-2016. Jurnal STIE Semarang, 11(2), 15-30.

Siti Nurlaela, S. A. M. D. (2017). Pengaruh Ukuran Perusahaan, Pertumbuhan Asset, Profitabilitas Dan Pertumbuhan Penjualan Terhadap Struktur Modal Perusahaan Cosmetics and Household Di Bursa Efek Indonesia. Jurnal Akuntansi Dan Pajak, 18(01), 16-30.

Suweta, N., \& Dewi, M. (2016). Pengaruh Pertumbuhan Penjualan, Struktur Aktiva, Dan Pertumbuhan Aktiva Terhadap Struktur Modal. Jurnal Manajemen Unud, 5(8), 254359.

Viandy, \& Dermawan, E. S. (2020). Pengaruh Profitabilitas, Struktur Aset, Likuiditas dan Pertumbuhan Penjualan Terhadap Struktur Modal. Jurnal Multiparadigma Akuntansi Tarumanagara, 2(April), 556-565.

Yoshendy, A., Achsani, N. A., \& Maulana, T. N. A. (2015). Analisis Faktor-Faktor yang Mempengaruhi Struktur Modal Perusahaan Barang Konsumsi di BEI tahun 2002 - 2011. Jurnal Bisnis Dan Manajemen, 16(1), 47-59.

Zulkarnain, M. (2020). Pengaruh Likuiditas Dan Profitabilitas Terhadap Struktur Modal. Jurnal IImu Dan Riset Manajemen, 22(1), 49-54. 